\title{
ASSESSMENT OF SEAWATER INTRUSION IN FUSHE KUQE AQUIFER, ALBANIA
}

\author{
Cenameri S. ${ }^{1}$ and Beqiraj A. ${ }^{1}$ \\ ${ }^{1}$ Faculty of Geology and Mining, Polytechnic University of Tirana, Tirana, Albania, \\ sabinacenameri@hotmail.com),arjan.beqiraj@fgjm.edu.al.
}

\begin{abstract}
The Fushë Kuqe costal aquifer is a typical confined alluvial aquifer. The aquifer medium consists of alternating and discontinuous layers of gravel and sand-gravel with and silt-clay impermeable layers which have conditioned its multilayer character. The aquifer recharge occurs mainly through water infiltration from the Mat river in the North, and from Droja river in the South, while its natural discharge proceeds to the Adriatic sea. As from the variation of chloride and TDS content in groundwater, an advancement of sea water intrusion into aquifer fresh water was evidenced. The direction of sea water wedge from coastal southwestern sectors towards the Gorre and Fushe Kuqe where pumping station are located, favors the opinion that it was caused by a decrease of groundwater pressure due to the groundwater pumping. The increase of chloride content in groundwater through time confirms that sea water intrusion towards the fresh aquifer water is still ad-vancing and is caused by both intensification of groundwater pumping for public water supply and by the drilling of artesian private wells.

Keywords: Sea water intrusion, chloride, aquifer.
\end{abstract}

\section{Introduction}

Seawater intrusion, which is a natural process that occurs in virtually all coastal aquifers, consists of salty water inflow from the sea towards freshwater aquifers and flowing inland. The first and oldest physical formulations of saltwater intrusion were made by Baydon-Ghyben $(1888,1889)$ and Herzberg (1901) and referred as the Ghyben-Herzberg formulation. Under natural, undisturbed conditions, a seaward hydraulic gradient exists in the aquifer with freshwater discharging into the sea. The heavier saltwater flows in from the sea and a wedge-shaped body of saltwater develop beneath the lighter freshwater, with the freshwater thickness decreasing from the wedge towards the sea.

The Fushë Kuqe costal aquifer is a typical confined alluvial aquifer. It is composed of alternating and discontinuous layers of gravel-sand-gravel and silt-clay. The water-saturated gravel-sand sediments range in thickness from $5-10 \mathrm{~m}$ in the East to $180-200 \mathrm{~m}$ in the West, whereas the thickness of silt-clay cover reaches up to 30-40m in the west (Eftimi et al, 1999).

The permeable gravel-sand layers of the alluvial deposits form a multi-layered aquifer which is mainly recharged through water infiltration from the Mat river in the North (Tartari et al., 2001). The direction of groundwater is from NE to SW and the groundwater discharges to the Adriatic sea. The piezometric head varies from about $0 \mathrm{~m}$ a.s.l. at the outlet of the river into the plain to about 3 $\mathrm{m}$ a.s.l. in the littoral, where the aquifer is confined (Tartari et al., 2001). Near the recharge area it 
appears as an individual semi-confined aquifer which changes towards the discharge zone to a multilayer confined one.

The good hydraulic connection between the aquifer and the sea, has prompted the intrusion of seawater toward freshwater of the aquifer. The intrusion phenomenon of seawater toward fresh water is well known in coastal aquifers. It is a natural phenomenon that has to do with the interaction of salt water and fresh water. Sea water intrusion affects primarily the deepest levels of aquifers, because salt water is heavier than fresh water. In natural conditions the border of fresh water - salt water represents a relative dispersion area which it can advance or withdraw conditioned by tidal effect, some year regime of rainfall, etc.

The phenomenon of sea water intrusion in Fushe Kuqe aquifer is especially stimulated by pumping of groundwater from the aquifer which reduce groundwater pressure and help sea water movement toward the aquifer. Using the $\mathrm{Cl}$ content of the groundwater, the seawater contribution in the aquifer ranges from $0 \%$ in the recharge zone to $5.5 \%$ in the coastal sectors of the aquifer.

\section{Geological and hydrogeological setting}

The Fushe Kuqe area is bordered to west by the Adriatic sea, and to NE by the Skanderbeu hills. The southern part of the Fushe Kuqe area extends up to Ishmit river, while its northern border is closed by the meanders of the Mat river (Fig. 1).

The study area represents a syncline of Neogenic sediments, composed of claystone and sandstone of the Tortonian and filled by Quaternary deposits. The Quaternary, mainly alluvial deposits usually fill the river valleys and some Periadriatic lowland plain synclines (Eftimi et al., 1999). The Quaternary sediments range in thickness from 5-10 $\mathrm{m}$ in the East to $180-200 \mathrm{~m}$ in the West and are composed of alternating and discontinuous layers of gravel-sand-gravel and silt-clay. Gravel crops out only along the course of the Mat river over a side area of some kilometers wide.

Regarding hydrogeology, the permeable gravel-sand layers of the alluvial deposits form a multilayered aquifer saturated with freshwater and covered by clay and silt, the thickness of which increases up to $30-40 \mathrm{~m}$. Therefore, the aquifer system is confined in the most of the studied area. The aquifer recharge likely occurs mainly through water infiltration from the Mat river bed in the North, by direct infiltration of rainfall in the gravel areas from the Droja river bed in the South, and, to a lesser extent, by groundwater seepage from lateral outcrops of permeable rocks bordering the area (limestone in the North). The natural discharge of the system proceeds to the Adriatic sea. In the Fushe Kuqe area, the aquifer is multifold because the presence of clay at different depth levels and in the alluvial delta of Mat River, the maximum thickness of the alluvial deposits is about 270 $\mathrm{m}$ and there are up to four gravelly aquifer layers (Eftimi 2003). In the Fushe Kuqe area, the direction of groundwater is from NE to SW, i.e. from the outlet of the Mat river into the plain, indicating that the main recharge is provided by the river itself, meandering through the gravel area. The piezometric head varies from about $0 \mathrm{~m}$ a.s.l. at the outlet of the river into the plain to about $3 \mathrm{~m}$ a.s.l. in the littoral, where the aquifer is confined (Tartari et al., 2001).

\section{Results and discussion}

Wet chemical analyses were performed on water samples. The surface of Fushe Kuqe gravelly aquifers affected by sea water intrusion constitutes about $15 \%$ (for the upper aquifer layer, however, the affected volume/resources ratio is much lower (Eftimi, 2003). 


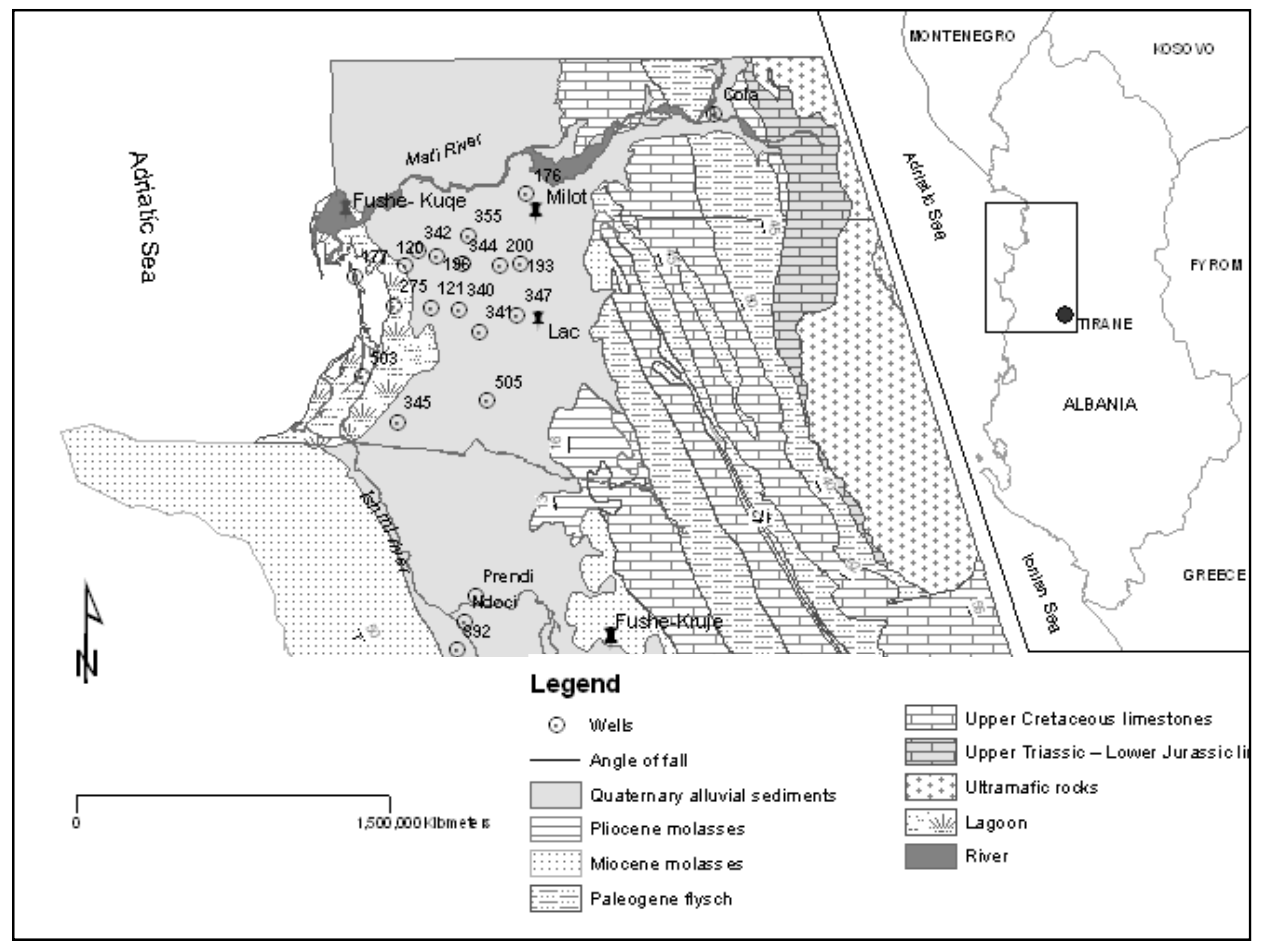

Figure 1 - Geological map of Fushe Kuqe region.

In general, the most affected areas by sea water intrusion are the peripheral ones having lower permeability and smaller water resources (Eftimi, 2003).

Groundwater salinity sharply increases in the area from about $2 \mathrm{~km}$ south of the Fushe Kuqe well field to the Droja river in the Adriatic sector, where it reaches as high as $1,500 \mathrm{mg} / \mathrm{l}$ in the first aquifer and 3,500 mg/l in the second. The cause of deterioration of the water quality has not yet being understood, probably it may be accounted for by a very low groundwater velocity in the area where the northern and southern parts of the plain join.

In figure 2 is shown the variation of chloride and TDS content in groundwater from well 503 through wells 341 and 340 up to well 193, that is, from southwest to northeast of the aquifer. Both chloride and TDS values increase southwestward, i.e. from recharge to discharge zone. In addition, from the map of TDS values (Fig. 3) and the map of hydrochemical water types (Fig. 4) it can be seen that sea water wedge that starts from southwest sectors (Adriatic) is oriented towards wells 196, 200, 193 where the groundwater production wells of the main pumping station are located. In fact, groundwater chemistry evolves from i) chemically immature groundwater, through ii) chemically more evolved groundwater to iii) highly evolved groundwater (Piper diagram, not shown), that is, from $\mathrm{Ca}-\mathrm{Mg}-\mathrm{HCO} 3$ type (in northeastern sectors) through $\mathrm{Mg}-\mathrm{Ca}-\mathrm{HCO} 3$ and Na-HCO3 (GorreFushe Kuqe) up to Na-Cl type (Adriatic) (Fig. 4). Based on chloride and sodium contents in the groundwater, the percentage of sea water in mixture was evaluated. It ranges from $0.0 \%$ in the groundwater from the well no. 193 through $2 \%$ in the groundwater from the well no. 340 up to about $5.5 \%$ in the groundwater from wells no. 341 and 503 .

The above evaluation (SW-NE) of the groundwater hydro-chemical parameters determines the orientation of salt water intrusion into the aquifer. This advancement of sea water intrusion into aquifer fresh water was probably conditioned by the following factors: 
Table 1 - Selected chemical analysis of Fushe Kuqe groundwater.

\begin{tabular}{|c|c|c|c|c|c|c|c|c|c|c|c|c|c|c|}
\hline Well no. & $\mathrm{T}$ & $\mathrm{pH}$ & $\mathrm{HCO} 3$ & SO4 & $\mathrm{Cl}$ & $\mathrm{Ca}$ & $\mathrm{Mg}$ & $\mathrm{Na}$ & $\mathrm{K}$ & NO3 & $\mathrm{PO} 4$ & $\mathrm{NH} 4$ & $\mathrm{Mp}$ & Fp \\
\hline 341 & 16.4 & 7.8 & 144 & 118 & 1038 & 104 & 95.9 & 476 & 5.47 & 0 & 0.6 & 0.038 & 2331 & 66.3 \\
\hline 503 & 16.4 & 7.56 & 283.5 & 24.75 & 1048.12 & 118.65 & 163.07 & 351.97 & 5.96 & 0.71 & 1.24 & 0.23 & 2452.4 & 96.9 \\
\hline 340 & 15.2 & 8.09 & 202.55 & 73.96 & 416.86 & 31.33 & 28.87 & 289.77 & 2.08 & 0 & 0.97 & 0 & 1182.2 & 19.7 \\
\hline 193 & 15.2 & 8.2 & 182.16 & 58.56 & 12.92 & 32.74 & 24.56 & 17.75 & 1.8 & 1.43 & 1.44 & 0.01 & 252.4 & 18.2 \\
\hline
\end{tabular}

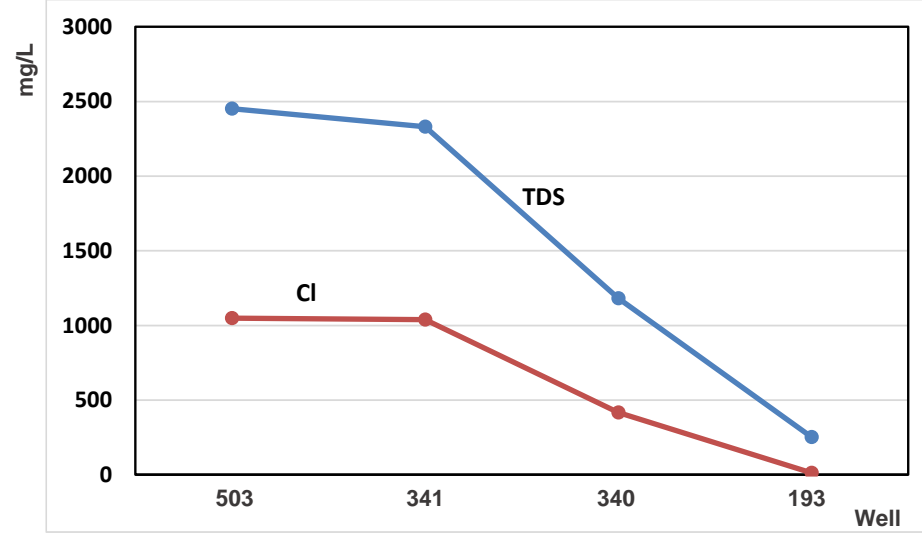

Figure 2 - SE-NW variation of $\mathrm{Cl}$ and TDS contents in groundwater.

- Low permeability properties of aquifer in the Adriatic sector, i.e. low pressure of fresh water, stimulated the relative advancement of sea water intrusion toward the Fushe Kuqe sectors.

- The intensification of pumping rates for public water supply and the increasing number of artesian private wells caused a gradual lowering of groundwater head, from about $8.0 \mathrm{~m}$ to $1.5 \mathrm{~m}$ above earth surface (Tartari et al., 2001) in the Fushe Kuqe sector which favored the sea water intrusion towards this area of the aquifer.

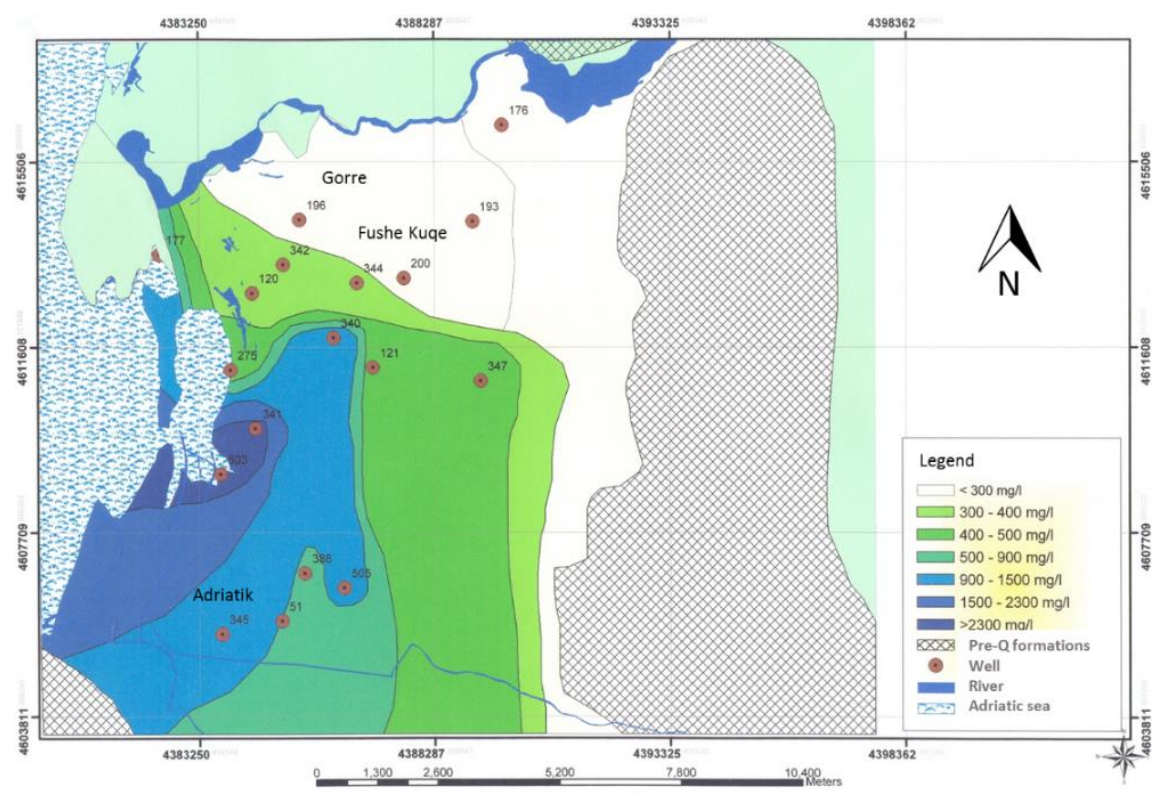

Figure 3 - Map of groundwater Total Dissolved Solids values. 


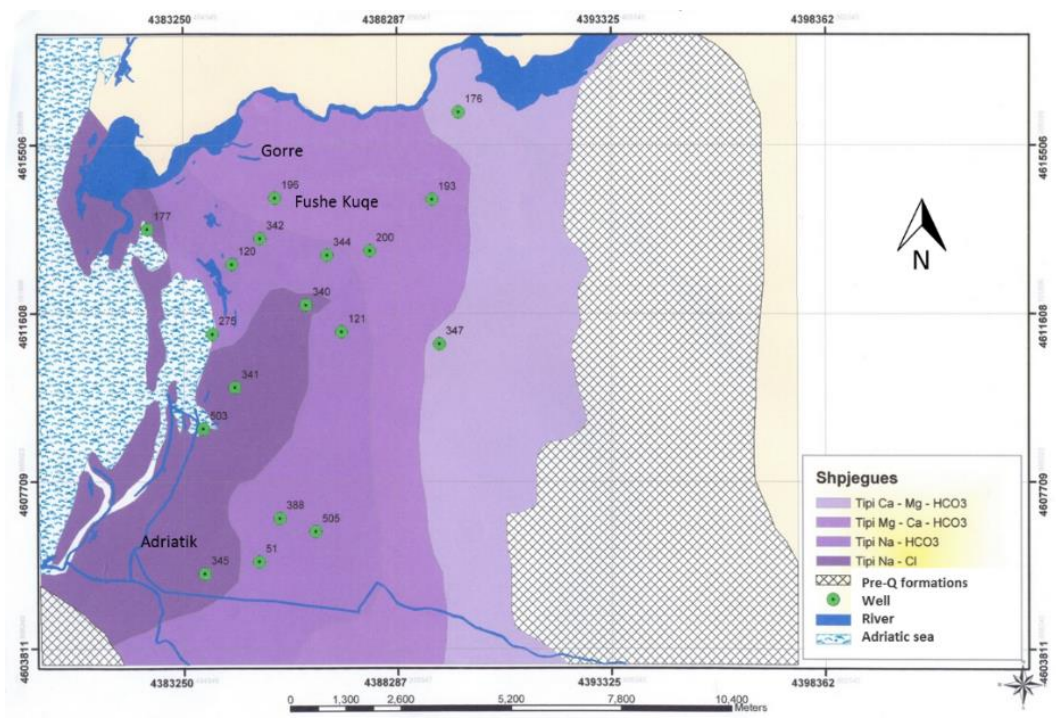

Figure 4 - Map of groundwater hydrochemical types.

In the table 2 and figure 5 is shown the variation of chloride content $(\mathrm{mg} / \mathrm{L})$ in wells 341 and 503 from the year 1984 through year 1999 up to year 2001). The chloride content of groundwater sampled from well no. 503 is gradually increased through time, while its content in the groundwater sampled from well no. 341, that is higher in the year 1984, is firstly lowered (year 199) and then increased (year 2001). Such a variation of chloride in the groundwater from the well no. 341 may be explained with depth of water sampling immediately after the well drilling. Because it is a typically artesian well, in 1999 and 2001, the groundwater was sampled from the mouth of the well.

Table 2 - The variation of chloride content $(\mathrm{mg} / \mathrm{L})$ in wells 341 and 503 through time (years 1984, 1999, 2001).

\begin{tabular}{|c|c|c|c|}
\hline Content of chloride $\left(\mathrm{Cl}^{-}\right)$ & 1984 & 1999 & 2001 \\
\hline Well 341 & 1136 & 1008 & 1037 \\
\hline Well 503 & 961 & 1070 & 1048 \\
\hline
\end{tabular}

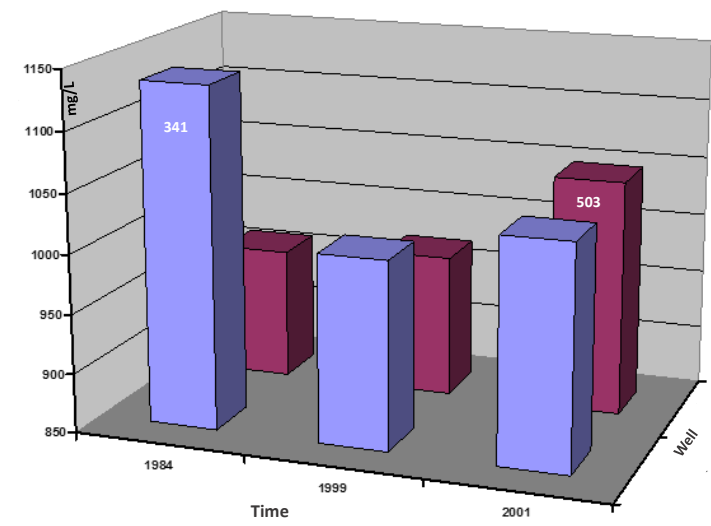

Figure 5 - The variation of chloride content $(\mathrm{mg} / \mathrm{L})$ in wells 341 and 503 through time (years 1984, 1999, 2001).

Further intensification of pumping in Gorre- Fushe Kuqe sector may further promote the advancement of salt water especially in the deeper levels of the aquifer. 


\section{Conclusions}

The aquifer of Fushe Kuqe is a typically confined aquifer composed of permeable gravel-sand layers of the alluvial deposits intercalated with impermeable clays characterizing it as a multi-layered aquifer.

Water infiltration from the Mat river bed towards aquifer represents the main recharge source, while the natural discharge of grounders under the Adriatic Sea bottom

Based on groundwater chemistry and, in particular, in its chloride content, sea water intrusion into fresh water of Fushe Kuqe aquifer was evidenced and the direction of its movement is from southwestern sectors towards the area of groundwater production wells of the main pumping station of Fushe Kuqe.

Sea water intrusion was probably caused by the decrease of groundwater pressure due to increasing groundwater pumping rates in the public production wells and increasing number of self-flowing water private wells.

Sea water intrusion is still advancing towards the aquifer fresh water as confirmed by the increase of chloride content in groundwater through time.

\section{References}

Beqiraj, A., Masi, U. and Barbieri, M., 2002. Caratteristiche geochimiche ed isotopiche di acque sotterranee del bacino idrogeologico di Tirana-Fushe Kuqe ed implicazioni per la Qualita', Botim special, 48-49, Elbasan, Albania.

Diogo, T. Bolster, A, Daniel, M. Tartakovsky, A. and Dentz. M., 2007. Analytical models of contami-nant transport in coastal aquifers.

Eftimi, R. and Tafilaj, I., 1979. Ujrat nentokesore te Shqiperise, Permbledhje Studimesh, 1, Tirane.

Eftimi, R., 2003. Some considerations on seawater-freshwater relationship in Albanian coastal area. In: Lopez-Geta, J.A., ed., Coastal aquifers intrusion technology: Mediterranean countries, Tome II, IGME, Madrid, 239-250.

Eftimi, R., Kolaneci, M. and Tafilaj, I., 1999. Groundwater resource management of Erzen-Ishmi River basin, Albanian Journal of Natural \& Technical Sciences, 7, 131-147.

Johnson, T., 2007. Battling Seawater Intrusion in the Central \& West Coast Basins, Technical Bulletin of Water Replenishment District of Southern California, 13.

KUMAR C.P., 2005. Modelling of Seawater Intrusion. National Institute of Hydrology, Roorkee (India).

Tartari, M., 2001. Vleresimi dhe mundesia e rritjes se rezervave te shfrytezueshme te ujrave nentokesore ne pelgun Tirane - Lezhe. SHGJSH. Tirane.

Uchiyama, Y., Nadaoka, K., Rolke, P., Adachi, K. and Yagi, H., 2000. Submarine groundwater discharge into the sea and associated nutrient transport in a sandy beach, Water Resources Research, 36(6), 1467-1479. 